\title{
Cytokine profiles of cultured microvascular endothelial cells from the human intestine
}

\author{
E M Nilsen, F-E Johansen, F L Jahnsen, K E A Lundin, T Scholz, P Brandtzaeg, \\ G Haraldsen
}

\begin{abstract}
Background and aims-Cytokine production by endothelial cells has, for practical reasons, been chiefly studied in human umbilical vein endothelial cells (HUVEC) but, because tissue-specific differences apparently exist, the role of human intestinal microvascular endothelial cells (HIMEC) as a source of mucosal cytokines was also assessed.

Methods-The expression of cytokine transcripts in HIMEC was screened by means of reverse transcription polymerase chain reaction (RT-PCR) and compared with cytokine profiles of HUVEC. Production of cytokines was investigated by bioassay and enzyme linked immunosorbent assay (ELISA).
\end{abstract}

Results-In the basal unstimulated state, HIMEC and HUVEC cultures contained detectable mRNA for interleukin (IL)-3, IL-7, IL-8, IL-11, IL-14, IL-15, tumour necrosis factor (TNF)- $\alpha$, transforming growth factor (TGF)- $\beta$, and granulocytemacrophage colony stimulating factor (GM-CSF). However, message was undetectable for IL-2, IL-4, IL-5, IL-9, IL-10, IL-12p40, IL-13, and interferon (IFN) $-\gamma$ in the resting as well as the stimulated state. Stimulation of HIMEC and HUVEC with recombinant human (rh) IL-1ß or rhTNF- $\alpha$ induced cell associated bioactive IL-1 $\alpha$ but not IL-1 $\beta$, as well as enhanced secretion of both IL-6 and IL-8. Furthermore, transcript levels for GM-CSF and

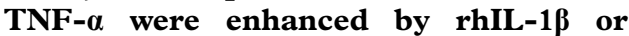
rhTNF- $\alpha$ in both cell types. Supernatants from Th1-like or Th0-like gluten reactive intestinal $T$ cell clones derived from patients with coeliac disease elicited cytokine profiles in both HIMEC and HUVEC similar to those revealed after

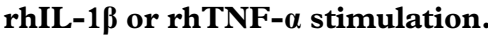

Conclusions-These data demonstrate that the intestinal microvascular endothelium may contribute to the cytokine network of the intestinal mucosa with the ability to respond to locally generated cytokines and to produce potent inflammatory mediators.

(Gut 1998;42:635-642)

Keywords: vascular endothelium; intestinal mucosa; cytokine profiles; mRNA; human

Correspondence to: Dr E M Nilsen, LIIPAT, Rikshospitalet, N-0027 Oslo, Norway.

Accepted for publication 31 October 1997

Recruitment of leucocytes from the circulation to sites of inflammation depends on both leucocyte and endothelial cell activation. In vitro studies of cultured endothelial cells have demonstrated that activation by bacterial endotoxin (LPS) or proinflammatory cytokines can increase or induce the endothelial expression of adhesion molecules and the production of cytokines. $^{12}$ These include interleukin (IL)-1 which may act in an autocrine fashion to enhance endothelial cell activation further, ${ }^{3-7}$ as well as production of IL-6, granulocytemacrophage colony stimulating factor (GMCSF), and transforming growth factor (TGF)- $\beta$, which may attract or activate more leucocytes. ${ }^{8-12}$ Also, endothelial cell activation may enhance the production of several chemokines (chemoattractant cytokines) such as IL-8, monocyte chemoattractant protein-1 (MCP-1), RANTES (regulated on activation, normal $\mathrm{T}$ cell expressed and secreted), and eotaxin; all these mediators may function in a juxtacrine fashion to attract or activate leucocytes. ${ }^{2}{ }^{13-17}$ In addition, endothelial cells have been reported to produce low levels of IL-3 as well as IL-11, cytokines suggested to play a role in the early haematopoietic system. ${ }^{18} 19$

For practical reasons, most in vitro studies have been performed with human umbilical vein endothelial cells (HUVEC), but increasing evidence both in vivo ${ }^{20}$ and in vitro ${ }^{22-25}$ suggests that considerable heterogeneity exists among endothelial cells from different tissues. Despite recent interest in microvascular endothelial cells, data concerning their cytokine profiles are apparently limited to a few studies on selected mediators. ${ }^{26}{ }^{27}$ The biological potential of microvascular endothelial cells from various human tissue compartments therefore remains elusive.

We have recently established a culture system for human intestinal microvascular endothelial cells (HIMEC) ${ }^{28}$ This enabled us to perform systematic analyses of their cytokine profiles with regard to mRNA expression and protein secretion, and to compare such data with cytokine profiles concomitantly displayed by HUVEC. Endothelial cell cultures were exposed to recombinant cytokines, lipopolysaccharide (LPS), or supernatants from gluten reactive $\mathrm{T}$ cell clones (TCC) from the small intestinal mucosa of patients with coeliac disease. The latter experiments were performed to mimic in vitro an immunopathological situation in the gut.

\section{Methods}

CYTOKINES, GROWTH FACTORS, AND OTHER REAGENTS
Recombinant human (rh) IL-1 $\beta\left(2.5 \times 10^{8} \mathrm{U} /\right.$ $\mathrm{mg})$, rhIL-6 $\left(2 \times 10^{6} \mathrm{U} / \mathrm{mg}\right)$, and $\mathrm{rh}$ tumour necrosis factor $(\mathrm{TNF})-\alpha\left(2 \times 10^{7} \mathrm{U} / \mathrm{mg}\right)$ were 
Table 1 Specifications of the primer sets used to analyse cytokine mRNA expression

\begin{tabular}{|c|c|c|c|}
\hline Cytokine & Primer set & $\begin{array}{l}\text { Annealing } \\
\text { temperature }\end{array}$ & $\begin{array}{l}\text { PCR product } \\
\text { size (bp) }\end{array}$ \\
\hline \multirow[t]{2}{*}{$\beta$-actin } & 5'-TGACGGGGTCACCCACACTGTGCCCATCTA-3' & 72 & 661 \\
\hline & 5'-CTAGAAGCATTGCGGTGGACGATGGAGGG-3' & & \\
\hline \multirow[t]{2}{*}{ IL- $1 \alpha$} & 5'-GTCTCTGAATCAGAAATCCTTCTATC-3' & 60 & 421 \\
\hline & 5'-CATGTCAAATTTCACTGCTTCATCC-3' & & \\
\hline \multirow[t]{2}{*}{ IL-1 $\beta$} & 5'-AAACAGATGAAGTGCTCCTTCCAGG-3' & 60 & 391 \\
\hline & 5'-TGGAGAACACCACTTGTTGCTCCA-3' & & \\
\hline \multirow[t]{2}{*}{ IL-2 } & 5'-GAATGGAATTAATAATTACAAGAATCCC-3' & 60 & 222 \\
\hline & 5'-TGTTTCAGATCCCTTTAGTTCCAG-3' & & \\
\hline \multirow[t]{2}{*}{ IL-3 } & 5'-TCCAAACATGAGCCGCCTGCC-3' & 60 & 211 \\
\hline & 5'-CATCAGAATGTCTTGGTCTTC-3' & & \\
\hline \multirow[t]{2}{*}{ IL-4 } & 5'-AACACAACTGAGAAGGAAACCTTC-3' & 65 & 276 \\
\hline & 5'-GCTCGAACACTTTGAATATTTCTC-3' & & \\
\hline \multirow[t]{2}{*}{ IL-5 } & 5'-GCTTCTGCATTTGAGTTTGCTAGCT-3' & 65 & 293 \\
\hline & 5'-TGGCCGTCAATGTATTTCTTTATTAAG-3' & & \\
\hline \multirow{2}{*}{ IL-6 } & 5'-ATGAACTCCTTCTCCACAAGCGC-3' & 60 & 628 \\
\hline & 5'-GAAGAGCCCTCAGGCTGGACTG-3' & & \\
\hline \multirow[t]{2}{*}{ IL-7 } & 5'-ATGTTCCATGTTTCTTTTAGGTATATCT-3' & 60 & 680 \\
\hline & 5'-TGCATTTCTCAAATGCCCTAATCCG-3' & & \\
\hline \multirow[t]{2}{*}{ IL-8 } & 5'-ATGACTTCCAAGCTGGCCGTGGCT-3' & 60 & 289 \\
\hline & 5'-ТСТСAGСССТСТTСАAАAACTТСТС-3' & & \\
\hline \multirow[t]{2}{*}{ IL-9 } & 5'-TCACCATGGTTCTGGCCATGGTCCTTACCTC-3' & 60 & 487 \\
\hline & 5'-ATAATATTTCATCTTCATATCTTGССТСТСA-3' & & \\
\hline \multirow[t]{2}{*}{ IL-10 } & 5'-ATGCCCCAAGCTGAGAACCAAGACCCA-3' & 72 & 352 \\
\hline & 5'-TCTCAAGGGGCTGGGTCAGCTATCCCA-3' & & \\
\hline \multirow[t]{2}{*}{ IL-1 1} & 5'-ACTGCTGCTGCTGAAGACTCGGCTGTGA-3' & 62 & 322 \\
\hline & 5'-ATGGGGAAGAGCCAGGGCAGAAGTCTGT-3' & & \\
\hline \multirow[t]{2}{*}{ IL-12p40 } & 5'-AGTGTCAAAAGCAGCAGAGG-3' & 60 & 363 \\
\hline & 5'-AACGCAGAATGTCAGGGAG-3' & & \\
\hline \multirow[t]{2}{*}{ IL-13 } & 5'-GCATGGTATGGAGCATCAAC-3' & 60 & 371 \\
\hline & 5'-ATTTTACСССТСССТАACCСТ-3' & & \\
\hline \multirow[t]{2}{*}{ IL-14 } & 5'-СССТCCAGTTCTTTATCC-3' & 55 & 224 \\
\hline & 5'-CAACAGCTTGCCCTATAC-3' & & \\
\hline \multirow{2}{*}{ IL-15 } & 5'-TGGAGCACAGAAATCAATG-3' & 55 & 265 \\
\hline & 5'-GAAACAGCCCAAAATGAAG-3' & & \\
\hline \multirow[t]{2}{*}{ IFN- $\gamma$} & 5'-ATGAAATATACAAGTTATATCTTGGCTTT-3' & 60 & 501 \\
\hline & 5'-GATGCTCTTCGACCTCGAAACAGCAT-3' & & \\
\hline \multirow[t]{2}{*}{ TNF- $\alpha$} & 5'-CGGGACGTGGAGCTGGCCGAGGAG-3' & 72 & 355 \\
\hline & 5'-CACCAGCTGGTTATCTCTCAGCTC-3' & & \\
\hline \multirow[t]{2}{*}{ TGF- $\beta 1$} & 5'-GCCCTGGACACCAACTATTGCT-3' & 65 & 161 \\
\hline & 5'-AGGCTCCAAATGTAGGGGCAGG-3' & & \\
\hline \multirow{2}{*}{ GM-CSF } & 5'-GAGCATGTGAATGCCATCCAGGAG-3' & 55 & 390 \\
\hline & 5'-CTCCTGGACTGGCTCCCAGCAGTCAAA-3' & & \\
\hline
\end{tabular}

obtained from Genzyme (Cambridge, Massachusetts, USA), rhIL-4 (ED $\left.{ }_{50} 0.05-0.2 \mathrm{ng} / \mathrm{ml}\right)$, rhIL-8 (ED $\left.{ }_{50} 0.15-0.3 \mu \mathrm{g} / \mathrm{ml}\right)$, and rh-interferon (IFN)- $\gamma\left(1 \times 10^{7} \mathrm{U} / \mathrm{mg}\right)$ from $\mathrm{R} \& \mathrm{D}$ systems (Abingdon, UK), while rhIL-10 (ED $\left.{ }_{50} 2 \mathrm{ng} / \mathrm{ml}\right)$ and rhIL-13 $\left(\mathrm{ED}_{50}<1.0 \mathrm{ng} / \mathrm{ml}\right)$ were obtained from Peprotech (London, UK). $\mathrm{N}^{6}, \mathrm{O}^{2}$-dibutyryl (db)-cAMP, $o$-phenylenediamine, ethidium bromide, epidermal growth factor, hydrocortisone, LPS (Escherichia coli serotype 026:B6), Tween 20 , and $p$-nitrophenyl phosphate were all purchased from Sigma Chemical Company (St Louis, Missouri, USA), and saponin from Serva Feinbiochemica (Heidelberg, Germany). Gentamicin and amphotericin B were obtained from Life Technologies (Paisley, Scotland, UK), and Trypsin/Versene solution from Biowhittaker (Walkersville, Maryland, USA). Murine leukaemia virus reverse transcriptase, AmpliTaq DNA polymerase, random hexamer, PCR buffer, and deoxynucleotide triphosphates (dNTP) were purchased from Perkin Elmer (Branchburg, New Jersey, USA), and RNasin was obtained from Promega Corporation (Madison, Wisconsin, USA). Oligo (dT) ${ }_{25}$-linked M-280 Dynabeads were purchased from Dynal (Oslo, Norway).

ANTIBODIES

Monoclonal antibody (mAb) to CD44 (clone F10-44-2, mouse IgG ${ }_{2 \mathrm{a}}, 1 \mu \mathrm{g} / \mathrm{ml}$ ) was obtained from Serotec (Oxford, UK), mAb to CD45 (clone PD7/26 and 2B11; mouse $\mathrm{IgG}_{1}, 1 / 50$ ),
$\mathrm{mAb}$ to $\mathrm{CD} 68$ (clone PG-M1, mouse $\mathrm{IgG}_{3}$, $18 \mu \mathrm{g} / \mathrm{ml})$, rabbit anti-human von Willebrand factor (vWf) (IgG fraction, 1/350); and rhodamine-labelled swine anti-rabbit IgG conjugate $(1 / 80)$ were purchased from Dako (Glostrup, Denmark); mAb to hIL-8 (clone 6217.11, mouse IgG, $1 \mu \mathrm{g} / \mathrm{ml}$ ) and biotinylated goat anti-hIL-8 (IgG fraction, $0.17 \mu \mathrm{g} / \mathrm{ml}$ ) were obtained from R\&D systems. Streptavidinfluorescein isothiocyanate (FITC) conjugate $(1 / 50)$ was purchased from Boehringer Mannheim (Mannheim, Germany), biotinylated horse anti-mouse IgG (1/20) from Vector Laboratories (Burlingame, California, USA), and horseradish peroxidase (HRP) conjugated streptavidin (1/1000) from Genzyme.

CULTURE MEDIA AND SERA

Endothelial-SFM and fetal calf serum (FCS) were purchased from Life Technologies, RPMI 1640 from Biowhittaker, and MCDB 131 from Sigma.

CELL CULTURE

HIMEC isolated from normal human jejunal mucosal/submucosal tissue were grown as described previously ${ }^{28}$ with minor modifications. Briefly, cells were dispersed from minced tissue by collagenase/dispase, plated, and grown to confluence in endothelial-SFM containing $2.5 \% \mathrm{FCS}, 1 \mu \mathrm{g} / \mathrm{ml}$ hydrocortisone, $0.5 \mathrm{mM} \mathrm{db}$-cAMP, $50 \mu \mathrm{g} / \mathrm{ml}$ gentamicin, and $0.25 \mu \mathrm{g} / \mathrm{ml}$ amphotericin B. Primary cultures 
A Stimulation |h)

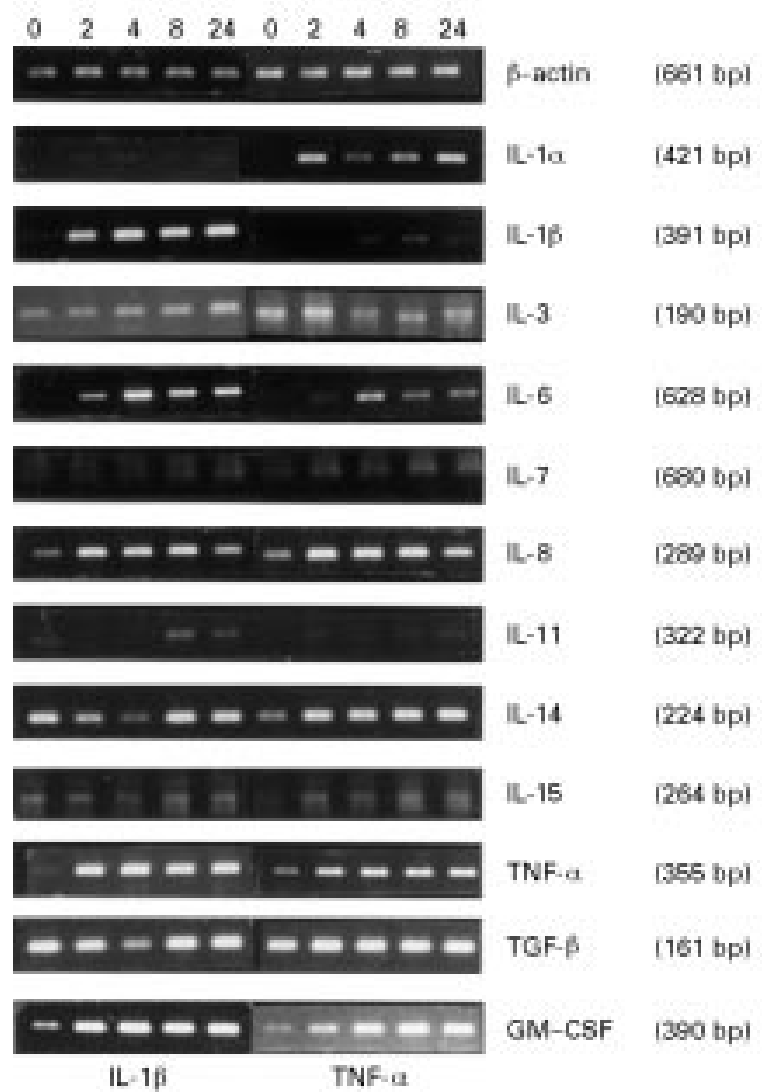

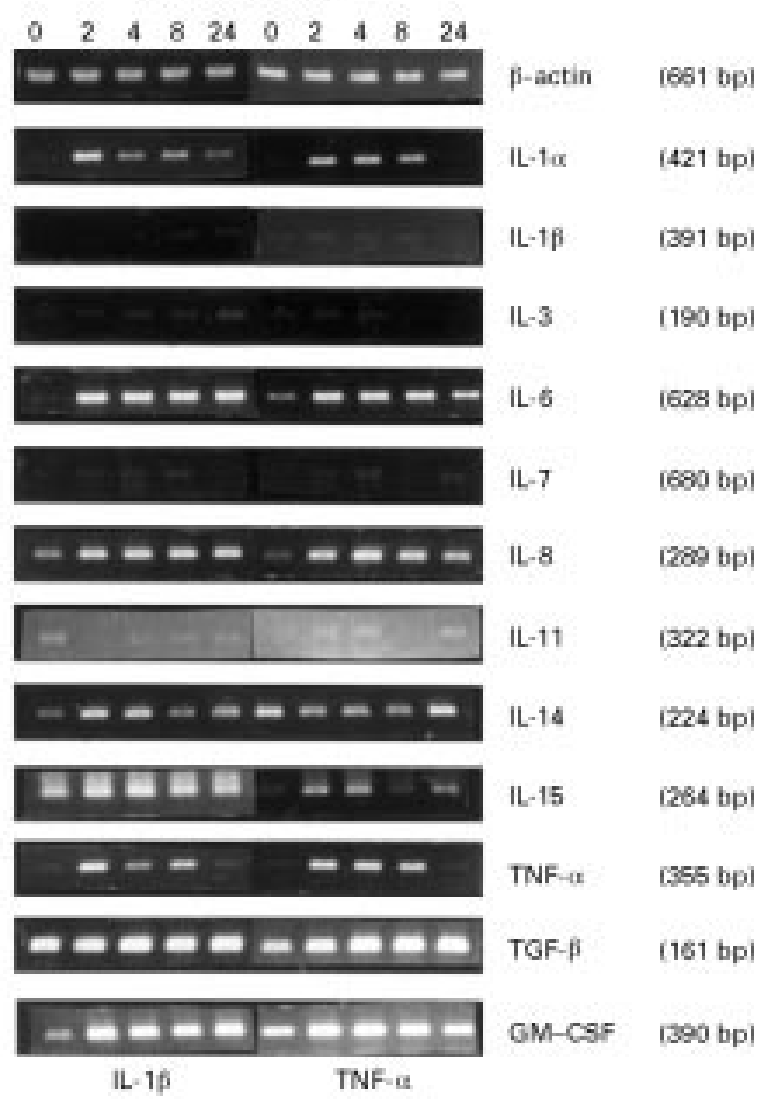

Figure 1 Semiquantitative determination of PCR amplified cytokine $m R N A$ in resting and cytokine-activated HIMEC and HUVEC. HIMEC (A) and HUVEC (B) were stimulated for two, four, eight and 24 hours. Amplification of reverse-transcribed poly $A^{+} R N A$ was performed by gene specific primers with $1 \mu \mathrm{l} c D N A$ for 25 cycles ( $\beta$-actin, IL-8, TGF- $\beta$, and GM-CSF), 30 cycles (IL-1a, IL-1 $\beta$, and IL-14), or 35 cycles (IL-3, IL-6, IL-7, IL-11, IL-15, and $T N F-a) . \beta$-actin served as sample control. Data are in each case representative of at least three separate experiments.

of adherent cells were then trypsinised and non-endothelial cells were eliminated by means of paramagnetic beads coated with $\mathrm{mAb}$ to CD $44 .^{25}$ Cells were, in the following passages, cultured in MCDB 131 as described below, but with the addition of db-cAMP. In some comparative experiments HIMEC were grown without db-cAMP for 48 hours before starting the experiments.

HUVEC were isolated as described by Jaffe et al. $^{29}$ Cells were grown in MCDB 131 containing $7.5 \% \quad \mathrm{FCS}, 10 \mathrm{ng} / \mathrm{ml}$ epidermal growth factor, $1 \mu \mathrm{g} / \mathrm{ml}$ hydrocortisone, $50 \mu \mathrm{g} /$ $\mathrm{ml}$ gentamicin, and $0.25 \mu \mathrm{g} / \mathrm{ml}$ amphotericin $\mathrm{B}$.

Seven HIMEC and three HUVEC cultures derived from individual donors were used at passage level 3-8. All endothelial cell cultures uniformly bound Ulex europaeus lectin I and were positive for vWf as assessed by immunocytochemistry on chamber slides.

Gut derived, HLA-DQ restricted, and gluten reactive TCC were generated from two patients with coeliac disease as detailed elsewhere. ${ }^{30} 31$ One clone came from a patient typed as HLA-DR3-DQ1,2, the other from a patient typed as HLA-DR4-DQ7,8. The TCC were cloned after 14 days in culture at 0.5 cells/well, expanded in RPMI 1640 containing $15 \%$ pooled human serum, $1 \mu \mathrm{g} / \mathrm{ml}$ phytohaemagglutinin, and $10 \mathrm{U} / \mathrm{ml}$ rhIL-2. To prepare the supernatants the TCC were stimulated with a peptic-tryptic digest of gluten in the presence of antigen presenting cells that expressed the relevant HLA class II restriction element. Supernatants were collected after 48 hours of stimulation, which was found to be the most optimal time point. ${ }^{32}$

POLYMERASE CHAIN REACTION OF

REVERSE-TRANSCRIBED mRNA

Semiquantitative analysis of cytokine mRNA expression was performed by reverse transcription (RT)-PCR. Polyadenylated RNA was isolated from $5 \times 10^{4}$ endothelial cells by means of M-280 Dynabeads coupled with oligo $(\mathrm{dT})_{25}$. Cells were solubilised in $200 \mu \mathrm{l}$ of lysis/binding

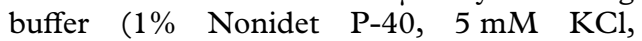
$500 \mathrm{mM} \mathrm{LiCl}, 200 \mathrm{mM}$ DTT, $10 \mathrm{mM}$ EDTA, $100 \mathrm{mM}$ Tris- $\mathrm{HCl}$ (pH 8.0), and $100 \mathrm{U} / \mathrm{ml}$ RNAsin) on ice for one minute, the lysates were centrifuged to remove cell nuclei, and the supernatants tranferred to a test tube containing $100 \mu \mathrm{g}$ of beads. After seven minutes of incubation at room temperature the beads were rinsed three times in washing buffer $(10 \mathrm{mM}$ Tris- $\mathrm{HCl}$ ( $\mathrm{pH} 8.0$ ), $0.15 \mathrm{M} \mathrm{LiCl}$, and $1 \mathrm{mM}$ EDTA). The mRNA was eluted from the beads at $65^{\circ} \mathrm{C}$ for two minutes in $10 \mu 1 \mathrm{DEPC}$-treated distilled water. Synthesis of cDNA was performed by RT of the mRNA eluate $(10 \mu \mathrm{l})$ in $20 \mu \mathrm{l}$ of a solution containing $5 \mathrm{mM} \mathrm{MgCl}_{2}$, $100 \mathrm{mM}$ Tris- $\mathrm{HCl}$ ( $\mathrm{pH}$ 8.3), $500 \mathrm{mM} \mathrm{KCl}$, $1 \mathrm{mM}$ deoxynucleotide triphosphates, $20 \mathrm{U}$ RNAsin, $50 \mathrm{U}$ of reverse transcriptase, and 
Table 2 Measurement of IL-1 protein in HIMEC cultures before and after cytokine stimulation

\begin{tabular}{|c|c|c|c|c|c|}
\hline \multirow[b]{2}{*}{ Production } & \multirow[b]{2}{*}{ None } & \multicolumn{2}{|c|}{$I L-1 \beta(100 \mathrm{U} / \mathrm{ml})$} & \multicolumn{2}{|c|}{$T N F-a(100 \mathrm{U} / \mathrm{ml})$} \\
\hline & & $6 h$ & $24 h$ & $6 h$ & $24 h$ \\
\hline \multicolumn{6}{|c|}{ Bioactive $I L-1$} \\
\hline Exp $1 \mathrm{SN}$ & Negative & ND & ND & $0.5 \mathrm{U} / \mathrm{ml}$ & $0.5 \mathrm{U} / \mathrm{ml}$ \\
\hline Exp 1 CL & Negative & ND & ND & $2 \mathrm{U} / \mathrm{ml}$ & $1 \mathrm{U} / \mathrm{ml}$ \\
\hline Exp $2 S N$ & Negative & ND & ND & Negative & $0.5 \mathrm{U} / \mathrm{ml}$ \\
\hline Exp 2 CL & Negative & ND & ND & $1 \mathrm{U} / \mathrm{ml}$ & $1 \mathrm{U} / \mathrm{ml}$ \\
\hline Exp $3 \mathrm{SN}$ & Negative & ND & ND & Negative & Negative \\
\hline Exp 3 CL & Negative & ND & ND & $15 \mathrm{U} / \mathrm{ml}$ & $30 \mathrm{U} / \mathrm{ml}$ \\
\hline \multicolumn{6}{|c|}{ Immunoreactive IL-1a } \\
\hline Exp $2 S N$ & ND & ND & ND & ND & ND \\
\hline Exp 2 CL & Negative & $15 \mathrm{pg} / \mathrm{ml}$ & $10 \mathrm{pg} / \mathrm{ml}$ & $8 \mathrm{pg} / \mathrm{ml}$ & $8 \mathrm{pg} / \mathrm{ml}$ \\
\hline Exp $3 \mathrm{SN}$ & Negative & ND & ND & Negative & Negative \\
\hline Exp 3 CL & Negative & ND & ND & $14 \mathrm{pg} / \mathrm{ml}$ & $30 \mathrm{pg} / \mathrm{ml}$ \\
\hline
\end{tabular}

$\mathrm{SN}$, supernatant; CL, cell lysate; ND, not determined.

$2.5 \mathrm{mM}$ random hexamer. RT was carried out for 10 minutes $\left(25^{\circ} \mathrm{C}\right)$ and 60 minutes $\left(42^{\circ} \mathrm{C}\right)$, followed by heat inactivation (10 minutes, $99^{\circ} \mathrm{C}$ ).

PCR was performed on $1 \mu \mathrm{l}$ cDNA and amplified by cytokine specific primers as described earlier. ${ }^{32}$ The number of cycles used for amplification of each cytokine is reported in the legends to figs 1 and 2. All primer sequences were derived from separate exons of the gene sequences, thus spanning intron(s); amplification products of genomic DNA could therefore be distinguished from products of reverse transcribed mRNA. The size of the PCR products, the primer set sequences, and the annealing temperatures for each primer set are given in table 1 .

\section{IMMUNOCYTOCHEMISTRY}

Endothelial cells were grown to confluence in chamber slides. Acetone-fixed monolayers (10 minutes, $20^{\circ} \mathrm{C}$ ) were first incubated for one hour with $\mathrm{mAb}$ to $\mathrm{CD} 44, \mathrm{CD} 45$, or CD68, then with rabbit anti-human vWf (IgG fraction) combined with biotinylated horse antimouse IgG for 1.5 hours, and finally with a rhodamine-labelled swine anti-rabbit IgG in combination with Streptavidin-FITC conjugate for one hour. The working concentrations are listed earlier. Positive controls were provided by mAb to ICAM-1 as well as frozen tissue sections from human intestine used as substrate for the primary mAbs. Negative controls were provided by concentration and isotype matched irrelevant mAbs.

Table 3 Cytokine production profile of one HUVEC culture before and after cytokine stimulation

\begin{tabular}{|c|c|c|c|c|c|}
\hline \multirow[b]{2}{*}{ Production } & \multirow[b]{2}{*}{ None } & \multicolumn{2}{|c|}{$I L-1 \beta(100 \mathrm{U} / \mathrm{ml})$} & \multicolumn{2}{|c|}{$T N F-a(100 \mathrm{U} / \mathrm{ml})$} \\
\hline & & $6 h$ & $24 h$ & $6 h$ & $24 h$ \\
\hline \multicolumn{6}{|l|}{ Bioactive $I L-1$} \\
\hline $\operatorname{Exp} 1 S N$ & Negative & ND & ND & $0.5 \mathrm{U} / \mathrm{ml}$ & $1 \mathrm{U} / \mathrm{ml}$ \\
\hline $\begin{array}{l}\text { Exp } 1 \mathrm{CL} \\
\text { Immunoreactive IL-1a }\end{array}$ & Negative & ND & ND & $15 \mathrm{U} / \mathrm{ml}$ & $20 \mathrm{U} / \mathrm{ml}$ \\
\hline Exp 1 SN IL-1 & Negative & ND & ND & Negative & Negative \\
\hline Exp 1 CL IL-1 & Negative & ND & ND & $15 \mathrm{pg} / \mathrm{ml}$ & $35 \mathrm{pg} / \mathrm{ml}$ \\
\hline Bioactive IL-6 & & & & & \\
\hline $\operatorname{Exp} 1 \mathrm{SN}$ & Negative & $24 \mathrm{U} / \mathrm{ml}$ & $32 \mathrm{U} / \mathrm{ml}$ & $3 \mathrm{U} / \mathrm{ml}$ & $16 \mathrm{U} / \mathrm{ml}$ \\
\hline $\begin{array}{l}\text { Exp } 1 \mathrm{CL} \\
\text { Immunoreactive IL-8 }\end{array}$ & Negative & $3 \mathrm{U} / \mathrm{ml}$ & $4 \mathrm{U} / \mathrm{ml}$ & $2 \mathrm{U} / \mathrm{ml}$ & $3 \mathrm{U} / \mathrm{ml}$ \\
\hline Exp 1 SN & $1.6 \mathrm{ng} / \mathrm{ml}$ & $26 \mathrm{ng} / \mathrm{ml}$ & $50 \mathrm{ng} / \mathrm{ml}$ & $12 \mathrm{ng} / \mathrm{ml}$ & $36 \mathrm{ng} / \mathrm{ml}$ \\
\hline Exp 1 CL & $0.5 \mathrm{ng} / \mathrm{ml}$ & $8 \mathrm{ng} / \mathrm{ml}$ & $12 \mathrm{ng} / \mathrm{ml}$ & $3 \mathrm{ng} / \mathrm{ml}$ & $4 \mathrm{ng} / \mathrm{ml}$ \\
\hline
\end{tabular}

$\mathrm{SN}$, supernatant; $\mathrm{CL}$, cell lysate; ND, not determined.
BIOASSAYS FOR CYTOKINES

IL-1 ( $\alpha$ and $\beta$ ) activity was determined in a proliferative bioassay by applying the cell line NOB-1 (mouse thymocyte EL-4 cell line) and the cell line HT-2 (mouse T-helper cell line). IL-6 activity was measured in a proliferative bioassay with the murine hybridoma cell line B9 (clone B-92504). These methods and their specificities have been detailed elsewhere. ${ }^{32}$

Cell lysates were prepared by repeated freeze-thawing cycles as described. ${ }^{33}$ Briefly, cells were washed once with medium, frozen at $-70^{\circ} \mathrm{C}$ (60 minutes), and thawed (60 minutes; $37^{\circ} \mathrm{C}$ ). The cells were subjected to three freeze-thawing cycles without removing the cell debris as described by Endres et al..$^{33}$

IMMUNOASSAYS FOR CYTOKINES

Commercial ELISA kits were used according to the manufacturer's recommendations for immunological quantification of IL- $1 \alpha$ and IL-1 $\beta$ (R\&D Systems). ELISA for hIL-8 was performed basically according to the manufacturer's recommendations (R\&D Systems). Briefly, 96-well plates were coated overnight at room temperature with murine anti-human IL-8 $\mathrm{mAb}$ and then blocked for two hours with $1 \%(\mathrm{w} / \mathrm{v})$ bovine serum albumin (BSA) in PBS $(\mathrm{pH} 7.4)$. The wells were rinsed six times in PBS containing $0.1 \%$ Tween 20 ; this washing procedure was repeated after each of the subsequent steps. Samples were incubated for one hour at $37^{\circ} \mathrm{C}$ and bound IL-8 was then detected by adding biotinylated goat antihIL-8 to each well for one hour at $37^{\circ} \mathrm{C}$. HRP conjugated streptavidin was then applied for 15 minutes at $37^{\circ} \mathrm{C}$. A substrate solution $(1 \mathrm{~g} / 1$ $o$-phenylenediamine in citrate buffer, $\mathrm{pH} 5$, containing $0.015 \% \mathrm{H}_{2} \mathrm{O}_{2}$ ) was added to each well and developed in darkness at $37^{\circ} \mathrm{C}$ for 5-15 minutes. The colour reaction was stopped with $2 \mathrm{M} \mathrm{HCl}$ and the optical density was read at $450 \mathrm{~nm}$ in a Titertek Multiskan Photometer (Helsinki, Finland), detecting less than $10 \mathrm{pg} / \mathrm{ml} \mathrm{rhIL-8}$ in our hands.

\section{Results}

RESTING HIMEC EXPRESS CYTOKINE TRANSCRIPTS RT-PCR was used to detect specific cytokine mRNA transcripts from confluent HIMEC and HUVEC cultures. A known amount of endothelial cells was used in all experiments; therefore a semiquantitative determination of the different cytokine transcripts could be performed by comparison with $\beta$-actin. In both types of cultures we detected mRNA for IL-3, IL-7, IL-8, IL-11, IL-14, IL-15, TNF- $\alpha$, TGF- $\beta$, and GM-CSF (fig 1 ). We were unable to detect message for IL- $1 \alpha$, IL-1 $\beta$, IL-2, IL-4, IL-5, IL-6, IL-9, IL-10, IL-12p40, IL-13, or IFN $-\gamma$ in resting endothelial cells despite the use of positive control cDNA.

The presence of transcripts for IL-7 and IL-14, cytokines presumably produced mainly by $T$ and $B$ cells, prompted us to exclude the presence of non-endothelial cells in the endothelial cell cultures. In both HIMEC and HUVEC, paired immunofluorescence staining with $\mathrm{mAb}$ to $\mathrm{CD} 44, \mathrm{CD} 45$ or CD68, combined with $\mathrm{Ab}$ to $\mathrm{vWf}$, revealed only weakly 
Table 4 Measurement of IL-6 and IL-8 protein in three HIMEC cultures before and after cytokine stimulation

\begin{tabular}{|c|c|c|c|c|c|}
\hline \multirow[b]{2}{*}{ Production } & \multirow[b]{2}{*}{ None } & \multicolumn{2}{|c|}{$I L-1 \beta(100 \mathrm{U} / \mathrm{ml})$} & \multicolumn{2}{|c|}{$T N F-a(100 \mathrm{U} / \mathrm{ml})$} \\
\hline & & $6 h$ & $24 h$ & $6 h$ & $24 h$ \\
\hline \multicolumn{6}{|c|}{ Bioactive IL-6 } \\
\hline Exp $1 \mathrm{SN}$ & Negative & $13 \mathrm{U} / \mathrm{ml}$ & $13 \mathrm{U} / \mathrm{ml}$ & $20 \mathrm{U} / \mathrm{ml}$ & $20 \mathrm{U} / \mathrm{ml}$ \\
\hline Exp $1 \mathrm{CL}$ & Negative & $13 \mathrm{U} / \mathrm{ml}$ & $13 \mathrm{U} / \mathrm{rnl}$ & $8 \mathrm{U} / \mathrm{ml}$ & $7 \mathrm{U} / \mathrm{ml}$ \\
\hline Exp $2 \mathrm{SN}$ & Negative & $16 \mathrm{U} / \mathrm{ml}$ & $18 \mathrm{U} / \mathrm{ml}$ & $18 \mathrm{U} / \mathrm{ml}$ & $5 \mathrm{U} / \mathrm{ml}$ \\
\hline Exp $2 \mathrm{CL}$ & Negative & $4 \mathrm{U} / \mathrm{ml}$ & $4 \mathrm{U} / \mathrm{ml}$ & $2 \mathrm{U} / \mathrm{ml}$ & $4 \mathrm{U} / \mathrm{ml}$ \\
\hline Exp $3 \mathrm{SN}$ & $1.5 \mathrm{U} / \mathrm{ml}$ & ND & ND & $1.5 \mathrm{U} / \mathrm{ml}$ & $1.5 \mathrm{U} / \mathrm{ml}$ \\
\hline Exp $3 \mathrm{CL}$ & Negative & ND & ND & $1.5 \mathrm{U} / \mathrm{ml}$ & $2.7 \mathrm{U} / \mathrm{ml}$ \\
\hline \multicolumn{6}{|c|}{ Immunoreactive $I L-8$} \\
\hline $\operatorname{Exp} 1 \mathrm{SN}$ & $10 \mathrm{ng} / \mathrm{ml}$ & $20 \mathrm{ng} / \mathrm{ml}$ & $50 \mathrm{ng} / \mathrm{ml}$ & $20 \mathrm{ng} / \mathrm{ml}$ & $35 \mathrm{ng} / \mathrm{ml}$ \\
\hline Exp 1 CL & $2 \mathrm{ng} / \mathrm{ml}$ & $6 \mathrm{ng} / \mathrm{ml}$ & $16 \mathrm{ng} / \mathrm{ml}$ & $4 \mathrm{ng} / \mathrm{ml}$ & $8 \mathrm{ng} / \mathrm{ml}$ \\
\hline Exp $2 S N$ & $15 \mathrm{ng} / \mathrm{ml}$ & $30 \mathrm{ng} / \mathrm{ml}$ & $40 \mathrm{ng} / \mathrm{ml}$ & $24 \mathrm{ng} / \mathrm{ml}$ & $30 \mathrm{ng} / \mathrm{rnl}$ \\
\hline $\operatorname{Exp} 2 \mathrm{CL}$ & $1.6 \mathrm{ng} / \mathrm{ml}$ & ND & $12 \mathrm{ng} / \mathrm{ml}$ & $\mathrm{ND}$ & $7 \mathrm{ng} / \mathrm{ml}$ \\
\hline Exp $3 \mathrm{SN}$ & $10 \mathrm{ng} / \mathrm{ml}$ & ND & ND & $10 \mathrm{ng} / \mathrm{ml}$ & $20 \mathrm{ng} / \mathrm{ml}$ \\
\hline $\operatorname{Exp} 3 \mathrm{CL}$ & $5 \mathrm{ng} / \mathrm{ml}$ & ND & ND & $7.5 \mathrm{ng} / \mathrm{rnl}$ & $25 \mathrm{ng} / \mathrm{ml}$ \\
\hline
\end{tabular}

SN, supernatant; CL, cell lysate; ND, not determined.

CD44 positive cells that were brightly vWf positive, whereas CD45 and CD68 were undetectable (data not shown). Also, the lack of transcripts for IFN- $\gamma$, IL-2, IL-4, IL-5, and IL-10 rendered the presence of T and B cells as well as macrophages unlikely.

HIMEC PRODUCE IL-1 $\alpha$ UPON CYTOKINE ACTIVATION

Stimulation of HIMEC with rhIL-1 $\beta$ (100 U/ $\mathrm{ml})$ or LPS $(1 \mu \mathrm{g} / \mathrm{ml})$ increased the mRNA level for IL- $1 \beta$ whereas that for IL- $1 \alpha$ appeared unchanged (fig 1A and data not shown). By contrast, stimulation with rhTNF- $\alpha(100 \mathrm{U} /$ $\mathrm{ml}$ ) increased IL- $1 \alpha$ mRNA, whereas IL-1 $\beta$ mRNA remained unchanged (fig 1A).

To evaluate the production of functional protein we used a proliferative bioassay that responds to both IL- $1 \alpha$ and IL- $1 \beta$. Supernatants $(2.5 \mathrm{ml})$ from $\mathrm{TNF}-\alpha$ stimulated HIMEC grown in six-well trays (approximately $10^{5}$ endothelial cells) contained only trace amounts of IL- 1 activity $(\leqslant 0.5 \mathrm{U} / \mathrm{ml})$, whereas cell lysates (dissolved in $1 \mathrm{ml}$ medium) induced proliferation corresponding to $1-30 \mathrm{U} / \mathrm{ml}$ of rhIL-1 $\beta$ (table 2 ). To determine whether the IL- 1 activity in the cell lysates was IL- $1 \alpha$ or IL-1 $\beta$, we tested for these cytokines separately by ELISA. In monocytes/macrophages IL- $1 \alpha$ has been shown to remain mainly cellassociated, whereas a large proportion of IL-1 $\beta$ is secreted. ${ }^{34}$ Consistent with this, cell lysates contained $8-30 \mathrm{pg} / \mathrm{ml} \mathrm{IL}-1 \alpha$ after stimulation with $\operatorname{rhTNF}-\alpha(100 \mathrm{U} / \mathrm{ml})$ for six or 24 hours (table 2), whereas IL-1 $\beta$ remained undetectable (data not shown). Likewise, cell lysates from IL-1 $\beta$-stimulated HIMEC contained $15 \mathrm{pg} / \mathrm{ml} \mathrm{IL}-1 \alpha$ after six hours and $10 \mathrm{pg} / \mathrm{ml}$ after 24 hours of stimulation (table 2). HIMEC supernatants contained neither IL-1 $\alpha$ (table 2) nor IL-1 $\beta$ (data not shown).

In HUVEC, rhIL-1 $\beta(100 \mathrm{U} / \mathrm{ml}), \operatorname{rhTNF}-\alpha$ $(100 \mathrm{U} / \mathrm{ml})$, or LPS $(1 \mu \mathrm{g} / \mathrm{ml})$ increased the mRNA level for IL- $1 \alpha$, whereas that for IL- $1 \beta$ appeared unchanged (fig $1 \mathrm{~B}$ and data not shown). Moreover, supernatants from TNF- $\alpha$ stimulated HUVEC contained only low amounts of IL-1 bioactivity $(0.5-1 \mathrm{U} / \mathrm{ml})$, while activity corresponding to $15-20 \mathrm{U} / \mathrm{ml}$ was found in the cell lysates (table 3 ). Furthermore, ELISA performed on cell lysates from HUVEC stimulated with rhTNF- $\alpha$ showed IL- $1 \alpha$ after six and 24 hours of stimulation (15 pg/ml and $35 \mathrm{pg} / \mathrm{ml}$, respectively; table 3), but no detectable IL-1 $\beta$ (data not shown). HUVEC supernatants contained neither IL- $1 \alpha$ (table 3) nor IL-1 $\beta$ (data not shown).

IL-6 AND IL-8 PRODUCTION IN HIMEC IS ENHANCED BY CYTOKINE ACTIVATION

Stimulation of both HIMEC and HUVEC with either rhIL-1 $\beta(100 \mathrm{U} / \mathrm{ml})$ or $\operatorname{rhTNF}-\alpha$
A

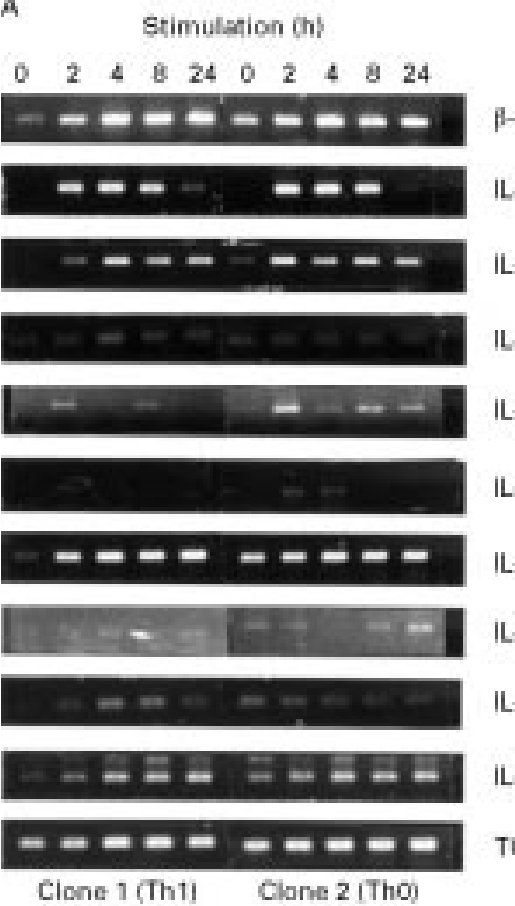

8

\section{Stimulation th:}

Figure 2 Semiquantitative determination of PCR amplified cytokine $m R N A$ after stimulation with supernatants from two gluten reactive $T$ cell clones isolated from coeliac disease mucosa. (A) HIMEC and (B) HUVEC were stimulated for two, four, eight, and 24 hours. One clone produced cytokines with a Th1-like profile, whereas the other produced a Th0-like profile as indicated in the figures. Amplification was performed as described in the legend to fig 1. 
(100 U/ml) increased IL-6 mRNA levels (fig 1). Furthermore, whereas unstimulated HIMEC and HUVEC produced negligible levels of bioactive IL- 6 protein, stimulation of both cell types for six or 24 hours with rhIL-1 $\beta$ or rhTNF- $\alpha$ resulted in the appearence of IL-6 in the range of $1.5-32 \mathrm{U} / \mathrm{ml}$ in both supernatants and cell lysates (tables 3 and 4 ).

Stimulation of both HIMEC and HUVEC with either rhIL-1 $\beta(100 \mathrm{U} / \mathrm{ml})$ or $\operatorname{rhTNF}-\alpha$ $(100 \mathrm{U} / \mathrm{ml})$ also appeared to increase the mRNA level for IL-8. Furthermore, ELISA measurements revealed $10-15 \mathrm{ng} / \mathrm{ml}$ of IL-8 in supernatants from resting HIMEC, while these levels were increased fivefold after 24 hours of IL- $1 \beta$ or TNF- $\alpha$ stimulation. Analysis of cell lysates revealed $1.6-5 \mathrm{ng} / \mathrm{ml}$ of IL- 8 in resting HIMEC which increased more than fourfold after IL-1 $\beta$ or TNF- $\alpha$ stimulation for 24 hours (table 4).

Supernatants from resting HUVEC contained $1.6 \mathrm{ng} / \mathrm{ml}$ of IL-8 which increased to $26 \mathrm{ng} / \mathrm{ml}$ after six hours and $50 \mathrm{ng} / \mathrm{ml}$ after 24 hours of IL- $1 \beta$ stimulation. TNF- $\alpha$ stimulation for six and 24 hours increased the levels to $12 \mathrm{ng} / \mathrm{ml}$ and $36 \mathrm{ng} / \mathrm{ml}$, respectively. Analysis of cell lysates revealed $0.5 \mathrm{ng} / \mathrm{ml}$ of IL-8 in resting HUVEC which increased to $12 \mathrm{ng} / \mathrm{ml}$ and $4 \mathrm{ng} / \mathrm{ml}$ after IL- $1 \beta$ or TNF- $\alpha$ stimulation, respectively (table 3 ).

EFFECT OF rhIL- $1 \beta$ OR rhTNF- $\alpha$ ON EXPRESSION OF OTHER CYTOKINES

Stimulation of HIMEC and HUVEC with rhIL-1 $\beta(100 \mathrm{U} / \mathrm{ml})$ or $\mathrm{rhTNF}-\alpha(100 \mathrm{U} / \mathrm{ml})$ for 2-24 hours increased the mRNA levels for GM-CSF and TNF- $\alpha$, whereas IL-3, IL-7, IL-11, IL-14, IL-15, and TGF- $\beta$ transcripts appeared to be unaffected (fig 1). Furthermore, such stimulation failed to induce detectable transcripts for IL-2, IL-4, IL-5, IL-9, IL-10, IL-12p40, IL-13, or IFN- $\gamma$ in both cell types (data not shown). Endothelial cell expression of IL-7, IL-14, IL-15, and TNF- $\alpha$ had not been previously described; the identities of the PCR products for these cytokines were therefore confirmed by sequencing or by nested primer PCR (data not shown).

EFFECT OF rhIL-4, rhIL-10, rhIL-13 OR rhIFN- $\gamma$ ON ENDOTHELIAL CELL CYTOKINE PROFILES

Stimulation of HIMEC and HUVEC with rhIL-4 $(10 \mathrm{ng} / \mathrm{ml})$ or $\mathrm{rhIFN}-\gamma(100 \mathrm{U} / \mathrm{ml})$ for 2-24 hours had only minimal effects. A small increase in IL- 6 and IL-8 mRNA expression was obtained but we were not able to detect an increase in the protein level (data not shown). Stimulation with rhIL-10 $(10 \mathrm{ng} / \mathrm{ml})$ or rhIL-13 (10 ng/ml) for 2-24 hours revealed neither increased mRNA levels for cytokines present in the resting state, nor induction of the other cytokines (data not shown).

EFFECT OF SUPERNATANTS FROM GUT DERIVED GLUTEN REACTIVE T CELL CLONES ON

ENDOTHELIAL CELL CYTOKINE PROFILES

To evaluate endothelial cell responses to stimulatory conditions mimicking those in the coeliac mucosa we stimulated HIMEC and HUVEC cultures with supernatants from two gluten reactive TCC isolated from in vitro stimulated biopsy specimens. $^{30} 31$ One TCC produced a Th1-like profile (clone 1) whereas the other produced a Th0-like profile (clone 2). ${ }^{32}$ Both clones produced IFN- $\gamma(2 \mathrm{ng} / \mathrm{ml}$ and $4 \mathrm{ng} / \mathrm{ml}$, respectively), TNF (10 U/ml and $500 \mathrm{U} / \mathrm{ml})$, and IL-6 $(400 \mathrm{U} / \mathrm{ml}$ and $500 \mathrm{U} /$ $\mathrm{ml})$, whereas clone 2 also produced IL-4 (4 ng/ $\mathrm{ml})$ and IL-5 (150 ng/ml). Production of IL-1 $\alpha$ and IL-1 $\beta$ was undetectable in both TCC. Stimulation of HIMEC and HUVEC with these TCC supernatants (diluted 1/3) increased the mRNA level for IL- $1 \alpha$, IL- $1 \beta$, IL- 6 , and IL-8, whereas the message for IL-3, IL-7, IL-11, IL-14, IL-15, or TGF- $\beta$ was not increased (fig 2) and that for IL-2, IL-4, IL-5, IL-9, IL-10, IFN- $\gamma$, or TNF- $\alpha$ remained negative (data not shown).

\section{Discussion}

This study has shown that microvascular endothelial cells from the human gut can constitutively produce several cytokines which are upregulated after stimulation with cytokines or LPS. In addition, we report a comparative analysis of cytokine profiles from cultured large and small vessel-derived endothelial cells. In vitro expression and regulation of cytokine production by endothelial cells have, for practical reasons, been chiefly described for HUVEC, but these cells may not exhibit characteristics of direct relevance to disease processes. On the other hand, data for microvascular endothelial cells are scarse and fragmented ${ }^{2627}$ and a systematic screening for cytokine transcripts has to our knowledge not been published even for HUVEC.

Bioactive cell associated IL-1 was found in HIMEC and HUVEC following stimulation with rhIL- $1 \beta$ or rhTNF- $\alpha$. ELISA measurements revealed the presence of IL-1 $\alpha$ in such cell lysates. This finding fits with previous studies which have described IL- $1 \alpha$ as an intracellular molecule whose precursor may associate with the surface membrane ${ }^{35}$ and activate adjacent cells. ${ }^{36} \mathrm{It}$ is also in agreement with findings reported by Kurt-Jones et a ${ }^{\beta}$ who demonstrated membrane bound IL-1 activity on activated HUVEC.

Our inability to detect IL- $1 \beta$ protein in both cell types requires some consideration. Under serum-free conditions HUVEC activated by LPS or TNF- $\alpha$ have been shown by means of a thymocyte costimulation assay to release IL-1 bioactivity. ${ }^{45}$ By the use of the same assay, Miossec et $a l^{6}$ showed that the presence of $20 \%$ FCS in HUVEC supernatants inhibited thymocyte proliferation. Furthermore, it has been demonstrated that prostaglandin $\mathrm{E}_{2}$ caused similar inhibition in supernatants from cultured saphenous vein endothelial cells. ${ }^{7}$ We therefore compared our standard growth medium $(7.5 \% \mathrm{FCS})$ with a low-serum medium (SFM-2.5\% FCS) and further examined the effect of indomethacin (known to inhibit synthesis of prostaglandins), in each case without detectable effect (unpublished results). The absence of IL-1 $\beta$ protein in the supernatants, despite detectable transcripts, might reflect reduced IL-1 $\beta$ translation despite 
substantial transcription, as reported for peripheral blood mononuclear cells ${ }^{37}$ and taken to be a first step in limiting the IL- $1 \beta$ activity. ${ }^{34}$ On the other hand, the presence of proIL-1 $\beta$, which is biologically inert, ${ }^{34}$ in the cellular cytoplasm could not be excluded because reactivity to this molecule is not guaranteed by the manufacturer of the ELISA kit used in this study.

Low constitutive levels of IL- 6 were found both in HIMEC and HUVEC, whereas increased expression and secretion of this cytokine occurred after stimulation with rhIL-1 $\beta$ or rhTNF- $\alpha$. Stimulation with rhIL-4 or rhIFN- $\gamma$ had minimal effect. It has been reported that IL-4 alone, but particularly in combination with IFN- $\gamma$, induces IL- 6 production in HUVEC. ${ }^{38}$ However, in that study the stimulation was performed for three days, while we stimulated endothelial cells for 24 and 48 hours in each case. IL- 6 has been reported to be chemotactic for $\mathrm{T}$ lymphocytes, ${ }^{39}$ and a recently published study showed that treatment of HUVEC with IL-6 increased their adhesiveness for peripheral blood lymphocytes ${ }^{8}$ indicating that IL- 6 may have a distinct role in the recruitment of lymphocytes into inflammatory lesions.

IL- 8 can be produced and secreted by several cell types. Nevertheless, its production by endothelial cells ${ }^{13-15}$ is of special interest because secretion of IL- 8 immediately at the tissue-blood interface may cause activation of adhering leucocytes if the cytokine is immobilised by glucosaminoglycans on the endothelial cell surface membrane. ${ }^{14} 40$

Low constitutive expression of both IL-3 and IL-11 mRNA in HIMEC and HUVEC was detected; stimulation with rhIL-1 $\beta$ or rhTNF- $\alpha$ did not result in an increase in message. Constitutive synthesis of IL-3 has been described in HUVEC, and in that report $\mathrm{TNF}-\alpha$ induced a slight increase in mRNA expression that we, in our study, were not able to detect. ${ }^{18}$ RhIL-3 has a weak effect on P-selectin expression in HUVEC ${ }^{41}$ and it also enhances eosinophil transendothelial migration, but biological effects of endothelial IL-3 have not been demonstrated. The constitutive presence of IL-11 mRNA accorded with a previous study on HUVEC, ${ }^{19}$ but the role of endothelial IL-11 production remains elusive.

In both cell types we also detected several cytokine transcripts that to our knowledge have not been previously described in endothelial cells; mRNAs for IL-7, IL-14, and IL-15 were all constitutively expressed in the cultures but apparently insensitive to cytokine induction. However, the endothelial origin of these cytokines will need confirmation because the extreme sensitivity of RT-PCR might reveal tiny amounts of mRNA from contaminating cells. Relatively strong expression of TGF- $\beta$ was found both constitutively and after stimulation with rhIL- $1 \beta$ or rhTNF- $\alpha$ in HIMEC and HUVEC cultures. Hannan and colleagues $^{42}$ described synthesis of an inactive latent form of TGF- $\beta$ in HUVEC but endothelial TGF- $\beta$ may be activated upon coculture with pericytes ${ }^{43}$ that are situated in the vessel wall of capillaries. Although not formally demonstrated, our transcript data suggested that HIMEC are able to produce TGF- $\beta$; once released, this cytokine might act as a potent monocyte chemoattractant ${ }^{11}$ as well as a stimulus for expression of leucocyte integrins. ${ }^{12}$

Constitutive expression of GM-CSF, which was increased after stimulation with rhIL- $1 \beta$ or rhTNF- $\alpha$, was found both in HIMEC and HUVEC. These findings accorded with previous studies that demonstrated GM-CSF production in resting and stimulated HUVEC. ${ }^{9}{ }^{10}$ Endothelial GM-CSF production could constitute an important step in the inflammatory process by functionally activating mature leucocytes at an inflammatory site, inhibiting their migration away from the focus, and also enhancing the proliferation and differentiation of progenitor cells. ${ }^{44}$

In considering the role of cytokines it should be emphasised that several of these molecules are present concomitantly or sequentially in vivo, allowing reciprocal amplification or inhibition of their expression. To address this issue we examined the endothelial cell response to supernatants from HLA-DQ restricted and gluten reactive TCC derived from coeliac disease lesions. These supernatants contained a complex mixture of cytokines, one clone showing a Th1-like profile and the other a Th0-like profile. We found almost the same cytokine pattern expressed by endothelial cells after this complex stimulation as after stimulation with rhIL- 1 or rhTNF- $\alpha$ alone. Thus, possibly different stimulatory effects of the two cytokine profiles of these supernatants, as well as different responses to stimulation by single recombinant cytokines, were quantitative rather than qualitative and would require more suitable PCR protocols or immunoassays to be defined.

Taken together, these data directly demonstrate that the intestinal microvascular endothelium may contribute to the cytokine network of the gut mucosa with the ability to respond to locally generated cytokines ${ }^{324546}$ and to produce potent inflammatory mediators. Additional studies are needed to clarify their putative role in vascular biology and pathology.

Eli Brundtland, Kathrine Kvien, Liv Mangschau, Tone Narvesen, and Inger Johanne Ryen are gratefully acknowledged for their expert technical assistance. We thank Dr Jarle Rugtveit for helpful discussions and Dr Audun E Berstad for help with the IL-8 ELISA. We are also grateful to the staff at the Maternity Unit, Department of Gynaecology, and to the staff at the Surgical Department B, Rikshospitalet, for assistance in obtaining tissue specimens. This study was supported by the Research Council of Norway, the Norwegian Cancer Society and the Council of Norway, the Norwegian Cancer Society, and the Medinnova Governmental Research Organization. EMN is a Fellow of the Norwegian Cancer Society.

1 Pober JS, Cotran RS. Cytokines and endothelial cell biology. Physiol Rev 1990;70:427-51.

2 Mantovani A, Bussolino F, Dejana E. Cytokine regulation of endothelial cell function. FASEB f 1992;6:2591-9.

3 Kurt-Jones EA, Fiers W, Pober JS. Membrane interleukin 1 induction on human endothelial cells and dermal fibroblasts. F Immunol 1987;139:2317-24.

4 Stern DM, Bank I, Nawroth PP, et al. Self-regulation of procoagulant events on the EC surface. F Exp Med 1985;162: 1223-35.

5 Nawroth PP, Bank I, Handley D, et al. TNF/cachectin interacts with EC receptors to induce release of IL-1. F Exp Med 1986;163:1363-75. 
6 Miossec P, Cavender D, Ziff $M$. Production of interleukin 1 by human endothelial cells. F Immunol 1986;136:2486-91. Warner SJC, Auger KR, Libby P. Interleukin
interleukin 1. f Immunol 1987;139:1911-17.

8 Watson C, Whittaker S, Smith N, et al. IL-6 acts on endothelial cells to preferentially increase their adherence for lymphocytes. Clin Exp Immunol 1996;105:112-19.

9 Broudy VC, Kaushansky K, Segal GM, et al. Tumor necrosis factor type $\alpha$ stimulates human endothelial cells to produce granulocyte/macrophage colony-stimulating factor. Proc Natl Acad Sci USA 1986;83:7467-71.

10 Sieff CA, Tsai S, Faller DV. Interleukin 1 induces cultured human endothelial cell production of granulocytemacrophage colony-stimulating factor. $\mathcal{F}$ Clin Invest 1987 79:48-51

11 Wahl SM, Hunt DA, Wakefield LM, et al. Transforming growth factor type $\beta$ induces monocyte chemotaxis and growth factor production. Proc Natl Acad Sci USA growth factor prod

12 Ignotz RA, Heino J, Massague J. Regulation of cell adhesion receptors by transforming growth factor- $\beta$. Regulation of vitronectin

13 Schröder JM, Christophers E. Secretion of novel and homologous neutrophil-activating peptides by LPSstimulated human endothelial cells. f Immunol 1989;142. 244-51.

14 Rot A. Endothelial cell binding of NAP-1/IL-8: role in neutrophil emigration. Immunol Today 1992;13:291-4.

15 Strieter RM, Kunkel SL, Showell HJ, et al. Endothelial cell gene expression of a neutrophil chemotactic factor by TNF- $\alpha$, LPS, and IL-1 $\beta$. Science 1989;243:1467-9.

16 Marfaing-Koka A, Devergne O, Gorgone G, et al. Regulation of the production of the RANTES chemokine by endothelial cells. Synergistic induction by IFN- $\gamma$ plus TNF- $\alpha$ and inhibition by IL-4 and IL-13. F Immunol 1995 ; 154:1870-8.

17 Garcia-Zepeda EA, Rothenberg ME, Ownbey RT, et al. Human eotaxin is a specific chemoattractant for eosinophil cells and provides a new mechanism to explain tissue eosinophilia. Nat Med 1996;2:449-56.

18 Andersen JC, Shelly CI, Galoforo SC, et al. Messenger RNAs for interleukin 3 are synthesized by human umbilical vein endothelial cells and regulated by inflammatory cytokines. VIIth International Symposium of the Biology of Vascular Cells, San Diego, California, 1992, Abstract 4.

19 Suen Y, Chang M, Min Lee S, et al. Regulation of IL-11 protein and mRNA expression in neonatal and adult fibroblasts and endothelial cells. Blood 1994;84:4125-34.

20 Swerlick RA, Lee $\mathrm{KH}$, Wick TM, et al. Human derma microvascular endothelial but not human umbilical vein endothelial cells express CD36 in vivo and in vitro. $f$ Immunol 1992;148:78-83

21 Shyjan AM, Bertagnolli M, Kenney CJ, et al. Human MAdCAM-1 demonstrates structural and functional similarities to the $\alpha 4 \beta 7$-integrin binding domains of murine MAdCAM-1, but extreme divergence of mucin-like sequences. F Immunol 1996;156:2851-7.

22 Swerlick RA, Lee KH, Li LJ, et al. Regulation of vascular cell Swerlick RA, Lee KH, Li LJ, et al. Regulation of vascular cell adhesion molecule 1 on human dermal micro

23 Gröger M, Sarmay G, Fiebiger E, et al. Dermal microvascular endothelial cells express CD 32 receptors in vivo and in vitro. F Immunol 1996;156:1549-56.

24 Haraldsen G, Kvale D, Lien B, et al. Cytokine-regulated expression of E-selectin, intercellular adhesion molecule-1 (ICAM-1), and vascular cell adhesion molecule-1 (VCAM-1) in human intestinal microvascular endothelial cells. F Immunol 1996;156:2558-65.

25 Jahnsen FL, Brandtzaeg P, Haye R, et al. Expression of functional VCAM-1 by cultured nasal polyp-derived microvascular endothelial cells. Am f Pathol 1997;150 2113-24
26 Bussolino F, De RM, Sica A, et al. Murine endothelioma cell lines transformed by polyoma middle $\mathrm{T}$ oncogene as target for and producers of cytokines. F Immunol 1991;147:21229.

27 Brown Z, Gerritsen ME, Carley WW, et al. Chemokine gene expression and secretion by cytokine-activated human microvascular endothelial cells: differential regulation of monocyte chemoattractant protein-1 and interleukin-8 in response to interferon- $\gamma$. Am f Pathol 1994;145:913-21.

28 Haraldsen G, Rugtveit J, Kvale D, et al. Isolation and long term culture of human intestinal microvascular endothelial cells. Gut 1995;37:225-34.

29 Jaffe EA, Nachman RL, Becker CG, et al. Culture of human endothelial cells derived from umbilical veins. 7 Clin Invest 1973;52:2745-56.

30 Lundin KEA, Scott $\mathrm{H}$, Hansen T, et al. Gliadin-specific, HLA-DQ $\left(\alpha 1^{\star} 0501, \beta 1^{\star} 0201\right)$ restricted $\mathrm{T}$ cells isolated from the small intestinal mucosa of celiac disease patients. from the Med 1993;178:187-96.

31 Lundin KEA, Scott $\mathrm{H}$, Fausa $\mathrm{O}$, et al. $\mathrm{T}$ cells from the small intestinal mucosa of a DR4, DQ7/DR4, DQ8 celiac disease patient preferentially recognize gliadin when presented by DQ8. Hum Immunol 1994:41:285-91.

32 Nilsen EM, Lundin KEA, Krajci P, et al. Gluten specific, HLA-DQ restricted $T$ cells from coeliac mucosa produce cytokines with Th1 or Th0 profile dominated by interferon

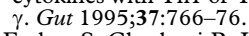

33 Endres S, Ghorbani R, Lonnemann G, et al. Measurement of immunoreactive interleukin-1 $\beta$ from human mononuclear cells: optimization of recovery, intrasubject consistency, and comparison with interleukin-1 $\alpha$ and tumor necrosis factor. Clin Immunol Immunopathol 1988;49:42438 .

34 Dinarello CA. The interleukin-1 family: 10 years of discovery. FASEB f 1994;8:1314-25.

35 Brody DT, Durum SK. Membrane IL-1: IL-1 $\alpha$ precursor binds to the plasma membrane via a lectin-like interaction. 7 Immunol 1989;143:1183-7.

36 Kaplanski G, Farnarier C, Kaplanski S, et al. Interleukin-1 induces interleukin-8 secretion from endothelial cells by a juxtacrine mechanism. Blood 1994;84:4242-8.

37 Schindler R, Clark BD, Dinarello CA. Dissociation between interleukin-1 $\beta$ mRNA and protein synthesis in human peripheral blood mononuclear cells. F Biol Chem 1990;265: 10232-7.

38 Howells G, Pham P, Taylor D, et al. Interleukin 4 induces nterleukin 6 production by endothelial cells: synergy with interferon- $\gamma$. Eur F Immunol 1991;21:97-101.

39 Bacon K, Gearing A, Camp R. Induction of in vitro human ymphocytes migration by interleukin 3 , interleukin 4 , and interleukin 6. Cytokine 1990;2:100-5.

40 Webb LMC, Ehrengruber MU, Clark-Lewis I, et al. Binding to heparan sulfate or heparin enhances neutrophil responses to interleukin 8. Proc Natl Acad Sci USA 1993; 90:7158-62.

41 Khew-Goodall Y, Butcher CM, Litwin MS, et al. Chronic expression of P-selectin on endothelial cells stimulated by the T-cell cytokine, interleukin-3. Blood 1996;87:1432-8.

42 Hannan RL, Kourembanas S, Flanders KC, et al. Endothelial cells synthesize basic fibroblast growth factor and translial cells synthesize basic fibroblast growth factor and tran
forming growth factor beta. Growth Factors $1988 ; 1: 7-17$.

43 Antonelli-Orlidge A, Saunders KB, Smith SR, et al. An activated form of TGF- $\beta$ is produced by co-cultures of endothelial cells and pericytes. Proc Natl Acad Sci USA 1989; 86:4544-8.

44 Rasko JEJ, Gough NM. Granulocyte-macrophage colony stimulating factor. In: Thomson AW, ed. The cytokine handbook. London: Academic Press, 1994:343-70.

45 Cominelli F, Kam L. Inflammatory mediators of inflammatory bowel disease. Curr Opin Gastroenterol 1993;9:534-3.

46 Sartor RB. Cytokines in intestinal inflammation: pathophysiological and clinical considerations. Gastroenterology 1994;106:533-9. 